\title{
Local Wisdom Based Tourist Village Organization in Lombok Tourist Area
}

\author{
Mohammad Irfan, Any Suryani
}

Faculty of law Mataram University, Indonesia

\begin{abstract}
Tourist village is an area of countryside which has some special characteristics to become a tourist destination. In this area, the population still has a tradition and culture are relatively pristine. In addition, some supporting factors such as food, agricultural system and the social system became one of coloring a tourist village.

The development of cultural tourism area in the hamlet of Sade tour to Lombok is arguably have not well-ordered. This cultural tourism area in terms of governance in pariwisataan support the activities particularly in the management of kampung adat Sade, typical handicraft tourism governance, governance of religious tourism sites the Customs still need more refinement continue. In the first year of the research revealed that this governance concepts strived for styled especially with regard to structuring awigawig tourist village that is encapsulated in the form of Regulations of the village in the hamlet of Sade tour and tourist village Segenter.

With data analysis method with approach of empirically packed can be generated, . Based on the objectives to be achieved in this study i.e., Increase community participation, increase the length of stay of tourists, Cultural Preservation so that found the concept of governance of the village tour Sade that is, organizing Neighborhood Village typical and custom, the Power Support infrastructure and Availability of land, Infrastructure, and human resources Management and the role of Government that can eventually be formulated strategy, a strategy that was used in an attempt to find the format layout Manage Replication: Sade tour hamlet hamlet of Sade, Sade Village Relocation, and Revitalizing the hamlet of Sade.
\end{abstract}

Keywords-Sade, Village governance, tourism, culture.

\section{INTRODUCTION}

West Nusa Tenggara island of Lombok is an island and is flanked by the island of Bali and Sumbawa, in this area during this time that stands out to the surface is a nautical and marine tourism area which is almost all the coastal area on the island of Lombok have it. If during this marine tourism and marine be a prima donna on the island of Lombok, it raises a question that tickles me now when we look at the dynamics of the other, i.e. tourism cultural tourism.

The dynamics of cultural tourism in Lombok, West Nusa Tenggara has brought the name of the province of Nusa Tenggara Barat to the vortex of national and international tourism industry, this phenomenon can be found in the cultural tourism in the realm of stretching local development quite significant from the start the habit of the population, the indigenous down temurunnya thick with local wisdom values, as well as the values of the ritual tradition and religion often gives its own charm for tourists. Local authorities have an important role in regulating and managing the direction and policy development in the area, on the island of Lombok Seems enough government apparatus synergize with tourism stakeholders in an effort to bring and advance the tourist areas, its sustainability will be we can see from the local tourism industry such as stretching the more typical woven fabric perjualan increasing customs such as gastric fabrics in Lombok. In the culture of Lombok's tourism, there are few places that became the best-selling enough tourist areas frequented by tourists, i.e. tourist village Segenter tourist village and Sade. Both this village has its unique cultural diversity and lure tourists. There are many indigenous cultures in both the uniqueness of the village the tour an exposé by coming out, but we see there are many factors that keep in clear in order to bring this village towards the order value is more towards the front.

Through the development of rural tourism or tourism village, then a tourism destination will have the diversity of tourist products that would open up opportunities return visit for tourists who travelled to the area. The principles of sustainable tourism should underlie the development of village tourism. Development of a power that goes beyond the support will cause a great impact not only on the environment but also on the socio-cultural life of the community that will ultimately affect the attractiveness of tourist villages, both in terms of positive or negative. 
Development of tourist villages should be able to be used as an attempt to preserve the uniqueness of the potential and empowering form of local culture and values of local wisdom which tends to undergo extinction due the current globalization and has entered the territory of the countryside.

The development of tourism culture in tourism and tourist village Segenter Sade Lombok arguably have not wellordered. This cultural tourism area in terms of governance in pariwisataan support the activities particularly in the management of perparkiran, the typical tourist craft governance, governance/revenue receipts from tourism visit still need further refinement. In the first year of the research revealed that this governance concepts strived for styled especially with regard to structuring awig-awig tourist village that is encapsulated in the form of Regulations of the village in the hamlet of Sade tour and tourist village Segenter.

When it will be built a traditional tourism concept setupbased culture, seem to need to consider the vision and mission of regional tourism NTB, his vision was to build Tourism NTB compete. Meanwhile, its mission is: (a) develop a tourism-based nature without destroying it; (b) appoint the local culture as a supporter of nature; (c) developing integrated tourism between nature and culture; (d) make the tour packages to introduce the whole potential; and (e) the empowerment of communities to increase tourism.

Data from the Ministry of tourism and creative economy mentions (2013), that Lombok Sade tour hamlet level excursions both foreign as well as domestic tourism tourism ranked Nine in Indonesia. We should give the shared appreciation so magnitude level excursions in particular traditional culture of Lombok. Research results related to it in the first year indicate that stretching the tour's traditional culture in the tourist village of Sade and the Segenter Lombok you shall need for further concrete measures, especially in the tourism governance improvement efforts of customs concerned with finding and designing new formats of traditional governance sustainable tourism on the island of Lombok, with emphasis on local wisdom values as its main foothold.

\subsection{Problems}

Based on the description above, it can be formulated as the following problems:

1. How does the Model Setup format of traditional Tourism tourism in the hamlet of Sade and Hamlet Segenter Lombok tours?
2. Evaluating the implementation of the Regulation of the village about the village that implicates to increased economic community stretching in the tourist village?

\section{THEORETICAL BASIS}

2.1 The concept of the traditional Tour Setup through the development of tourist villages

The literature review which became a reference for researchers, research results are first year, successfully formulated the concept of structuring the tourism village with the concept of structuring, 1. Perlibatan of indigenous peoples in the management of tourist asset, in this case a tourist village communities should be involved in the activities of the aktiv routines such as the management of perparkiran diareal village, should the management of perparkiran according to the awig - awig that their personal religious beliefs, namely a possible perpetrator of the perparkiran revenue by attracting perpakiran levy in accordance with the agreement of the citizens of the village. As long as this trend is happening in the management of custom tours in the hamlet of perparkiran, there has been no official arrangement be footing the indigenous citizens therefore need for the involvement of citizens in shaping the concept of custom awig-awig in the management area of the perparkiran so that the atmosphere of the comfort of the tourists who visit. 2. Synergy between the interests of tourists and local community interests. Support the development of tourist visits in the village need to let agreed and understood between the needs of tourists who come to visit which significantly implies the increasing income of the local community of the village of Sade as a result the visit and the interests of indigenous peoples in this Sade, indigenous peoples should cultivate Sade soul maximum service in any area of the side of tourists visit.

Tourist village communities should be able to demonstrate how to cultivate an attitude of indigenous culture heritage hospitality which upholds the feelings never hurting others, which they believe to be part of the awig - awig is not written that have veined rooted.

Ray utama I gusti bagus (2015), Hospitality catering is one way good service synergy between the desire of tourists and the desire of indigenous tourism village. 3. Actions of the Ministry of tourism for proaktiv all stakeholders with an interest in indigenous tourism Sade, in indigenous culture indigenous village tours, custom, custom Head Regent and head of the village as well as a collection of indigenous citizens in an attempt to give and creating an indigenous village of Sade and landscaped berkultural the elements 
element should unify the vision and mission to contribute in advancing indigenous tourism Sade by doing various active steps such as, maintains and keep the values so awig-awig don't get eroded by various parties in the interests of the other party directly affected awig-awig existence against village Customs.

Awig-awig village existence this custom must remain awake therefore to stakeholders is required of its role in maintaining the local community into a tourist village with community kebangggaan increasing Treasury awig-awig for the importance of sustainable tourism in the tourist village. Along with that, various things can be done in order to continue to provide their fair share to keep the creation of atmosphere conducive to remain terlestarinya the current tourists visit indigenous villages in Sade while upholding the values of the local wisdom values awig-awig form is meant to be an unwritten rule frames that fosters an atmosphere of comfort for tourists visiting the indigenous residents or Sade in General.

The village government as authorities and regulators in formulating awig-awig as must have full involvement when awig-awig keep an as one unified whole jointly owned indigenous village tour, of course with the movement all the elements are there in the village of Rembitan in particular maintain and safeguard harmony awig-awig as a foothold or guide in the everyday culture of the community of the village tourism. 4. In order to re-arrange the awig - awig indigenous village tour as supporting tourism, it's good to make the traditional tourism climate is good, may access for local businessmen to develop various knick knacks tourism traditional custom. Grow local entrepreneurs access important in indigenous traditional tourist areas should be given freedom by stakeholders by applying awig-awig which accommodate arranged in realizing indigenous Hamlet as Hamlet.

\subsection{Tourist Village}

Tourist village is a form of integration between attractions, accommodation and supporting facilities are presented in a structure of people's lives that blends with the Ordinances and tradition Wiendu Nuryanti (1993). Therefore the local community should be actively involved in identifying assets that will be used in any form of rural tourism development.

Nzama, T.A. (2010) delivered three main components that are necessary as a foundation in the development of tourist villages:

1. the Infrastructure (roads, electricity etc.)

2. Materials (natural resources, public and private structures, etc.)
3. material Components (capacity of local communities to take advantage of the existing resources, the condition of the political and socialcultural environment.

\subsection{The Hamlet Of Sade}

The hamlet of Sade has had a tourism attraction in the form of the unique culture of the society reflects the culture of the native Sasak community still able to survive amid the fierce life of modernization. Is said to be unique because the daily life of the community is indeed very different from life in General. Starting from their home living, everyday activity up to a wealth of cultural attractions is very interesting and worthy of being displayed for tourists.

The shape of the House lit tares, berdindingkan of land and the other half bedeg (woven bamboo in the form of sheets) and the ground-floor, is the utilization of existing material surrounding them and indicate the authenticity of indigenous Sasak House. Very interesting things and seen strange for tourists is a resident of the hamlet of Sade MOP the floor using cow dung or buffalo herds still wet in a State without the use of the cover is hand. Along with the progress of the times, and the development of Islam in the hamlet of Sade this tradition has not been done yet, because Buffalo dung, according to the teachings of Islam five is considered unclean.

The position of the village because it is lucrative Sade a one line heading to the beach Kuta Lombok is very beautiful and the exotis, making the tourists do not have to think long to take the "drop by" to the hamlet of Sade. Plus also has been operating as the international airport in Lombok (BIL), which is only approximately $3 \mathrm{~km}$ with it takes about 10 minutes to the hamlet of Sade increasingly facilitate travelers visiting the hamlet of Sade.

It seems clear on the number of tourists to visit the hamlet of Sade that tend to show increased as shown in table 1. below:

Table.1: Tourists visit in the hamlet of Sade Years 2010

2016

\begin{tabular}{|c|c|c|c|c|c|}
\hline \multirow{2}{*}{$\begin{array}{c}\mathrm{N} \\
\mathrm{O}\end{array}$} & \multirow{2}{*}{ TAHUN } & \multicolumn{2}{|c|}{ WISATAWAN } & \multirow{2}{*}{ JUMLAH } & \multirow{2}{*}{$\%$} \\
\cline { 3 - 4 } & & WISNUS & WISMAN & & \\
\hline 1. & 2010 & 12.837 & 9.125 & 21.962 & \\
\hline 2. & 2011 & 10.125 & 8.160 & 18.285 & $-16,74$ \\
\hline 3. & 2012 & 16.638 & 8.772 & 25.410 & 38,97 \\
\hline 4. & 2013 & 17.653 & 15.601 & 33.254 & 30,87 \\
\hline 5. & 2014 & 17.672 & 13.721 & 31.393 & $-5,60$ \\
\hline 6. & 2015 & 30.105 & 19.036 & 49.141 & 56,53 \\
\hline 7. & 2016 & 46.332 & 22.825 & 69.157 & 40,73 \\
\hline
\end{tabular}


Source: Department of culture and tourism central Lombok Regency

See the trend increase in tourists visit mainly tourists visit the archipelago from the year 2010 until the year 2016, it appears that the hamlet of Sade has an enormous opportunity to be developed as a tourist destination.

\subsection{Corporate governance of traditional Village tourist attractions in Lombok culture tourism area}

In line with the development of tourism, the motion dynamics of permeates in different terminology such as, sustainable tourism development, rural tourism, ecotourism, tourism development approach that is working to ensure that tours can be implemented in tourist destination rather than urban areas. One of the approaches to the development of alternative tourism is tourism for sustainable rural development in the field of tourism

Maksimilianus Maris Jupir (2013), Tourist village is an area of countryside which has some special characteristics to become a tourist destination. In this area, the population still has a tradition and culture are relatively pristine. In addition, some supporting factors such as food, agricultural system and the social system became one of coloring a tourist village. Outside factors these factors, nature and the environment and awake is one of the most important factors of a tourist destination.

Tourists who come to the village it will be able to enjoy the natural countryside clean and feel alive disuasana village with a number of customs and traditions. Dewi winarny susyanti (2013), Tourists staying with residents, sleeping in bed that is simple but clean and healthy, traditional foods is the main dishes served during the tour in the village, tourists feel any satisfaction due to the welcoming, and service of the population of the village. in order to improve tourism activities through community-based empowerment.

\section{METHODOLOGY OF RESEARCH}

This research was conducted in the hamlet of Sade are situated in the village Rembitan, district Pujut located south of Praya, central Lombok Regency. The naming of the village as a location for research because Sade Sade is the only one of the oldest traditional Sasak village and 11 (eleven) regional tourism as well as strategic areas near the area of the development of the special economic area of Mandalika.

Engineering data collection done on natural conditions with observations contribute or participate (participant observation), interview (interview) and documentation. Determination of the source of the data on the people who will be interviewed in this study done on a purposive, i.e. selected with consideration of the particular and specific purpose. By pointing out some of the expert or experts as the informant who mastered and understood about the development of tourism in the hamlet of Sade is expected to be retrieved information in determining the priority of the strategy is the development of the hamlet of Sade as a tourist village.

\subsection{Technique Of Data Analysis Analytical Hierarcy Process (AHP)}

Analytic Hierarchy Process (AHP) is one form of a decision-making model that is basically trying to cover up the shortcomings of other decision-making model. The main tool in the model of AHP is a functional hierarchy with the main input in the form of human perception. With a hierarchy, an issue that was complex and not measurable are broken down into group $\neg$ the Group and then the groups are organized into a hierarchical form (Brojonegoro, 1992).

AHP can simplify a complex issue and is not structured, strategic and dynamic became part of it, as well as make variables in a hierarchy (levels).

\section{FINDINGS AND DISCUSSIONS}

In this study the format of governance that will be used in determining the strategy for development of the region of the village is the Tourist village of Sade as a chart hierarchy in Figure 4.1. 


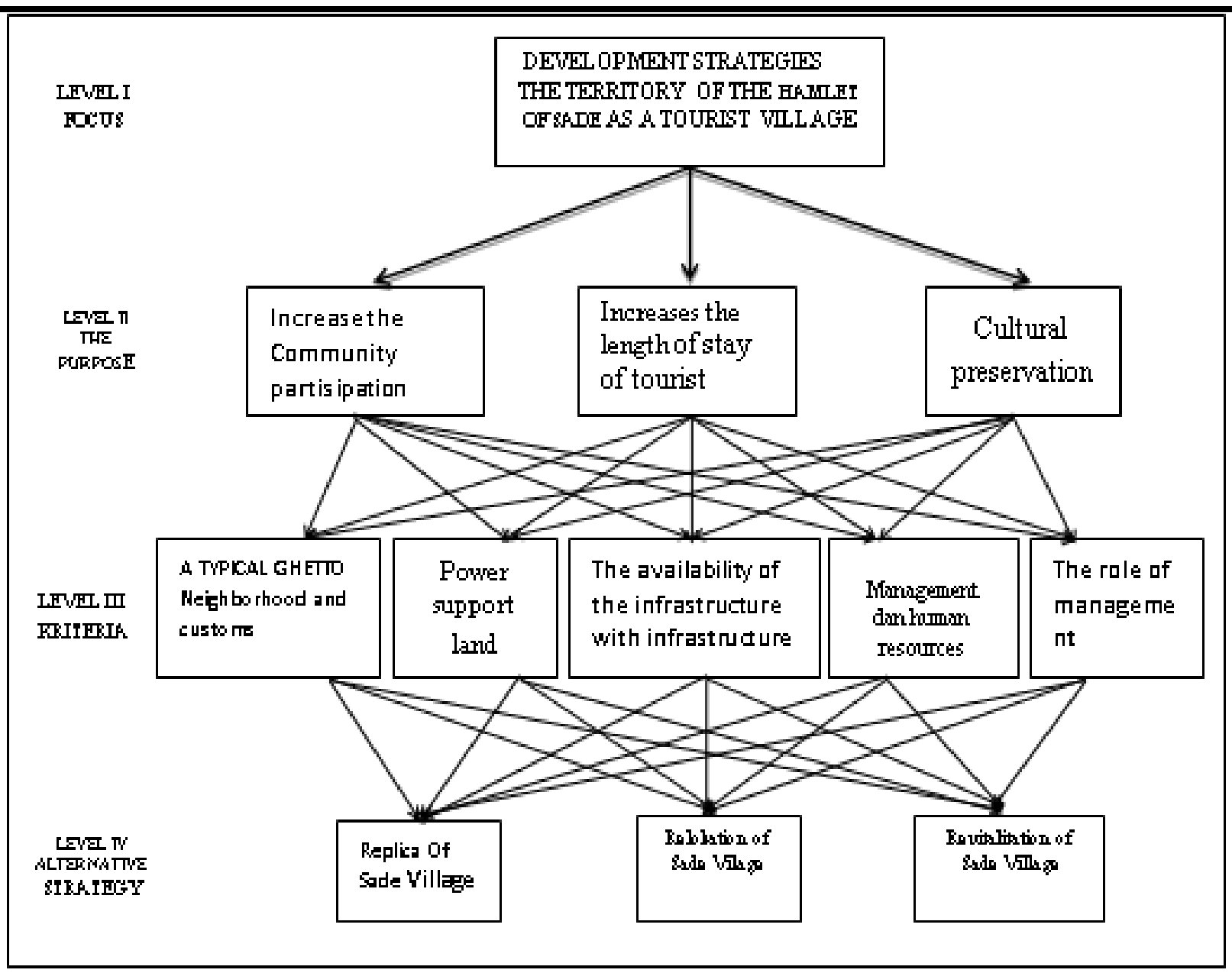

Fig.4.1: Model AHP Hierarchy Chart

Level 1 is the focus in this study is a strategy development of the region of the village of Sade as a tourist village. Level 2 is the priority main aim shall be achieved in the development of the territory of the hamlet of Sade as a tourist village, goals to be achieved as follows:

\subsection{Increase public participation}

Development of tourist villages provide the perceived economic benefits directly or indirectly by local people. Therefore the development of a tourist village need to involve the participation of local communities. The readiness of the community received strong commitment towards activities and tourism will create interaction between local communities as hosts with travelers as a guest so that fosters mutual respect and further provide the benefits of a lucrative form of community welfare local and local communities will simultaneously while maintaining sustainability culture. Development of tourist villages requires passion and strong motivation from the public in maintaining the character of the natural physical environment typical of the countryside and cultural life which live and grow in the local community.

Development of the region of the village of Sade as a tourist village provides socio-economic benefits for the community and surrounding areas with Sade opening employment opportunities, or even make the community self-sufficient economically. The local community is guard resources on their territory such as socio-cultural resources and their cultural heritage resources. Therefore the local community should be actively involved in identifying assets that will be used in any form of rural tourism development. Public participation is a contribution to society as real and positive towards the preparation of the planning and implementation of development in the regions. The community contribute in identifying the regional development programmes according to the needs of the region, the potential and the desire of community groups. 
4.2. Increase the length of stay of tourists (foreign tourist lenght of stay)

Development of the hamlet of Sade as a tourist destination will have a direct impact on improving the economy of the local community and of course the double impact for the people of the surrounding villages. In line with the directive of the Ministry of culture and tourism in Renstra delivered that benchmark the success of tourism development to gain revenue is the amount of visits, tourist spending and length of stay (tourist 2010). Conditions that occur at the time of visiting tourists is Sade is very short because most tourists who come have been tied to packages they buy, where time visits to Sade is just 1 hour. Whereas the community's everyday life, the Sade who is still upholding the customs, can be packed into an exciting tour package. Facilities or services that support the comfort of accommodation to tourists, there is still no around Sade.

\subsection{Preserving cultural}

The hamlet of Sade as a traditional hometown Sasak Tribe is one of the oldest group of Sasak in Lombok. As a tourist destination, Sade has the potential appeal of a unique and distinctive that is the capital of the Foundation for the development of a rural region into a tourist village so as to attract tourists to come visit him. Sasak culture that is part of the culture of Nusa Tenggara Barat should remain preserved as a richness and pride of the region. In terms of the importance of tourism, the local characteristics of a region can be a interesting attractions for tourists.

At level 3, there are criteria that must be met in an effort to make the development of the region of the village of Sade as a tourist village. Criteria is the criteria that must be met in the development of village tourism. Village tourism as one of the product tours generally have a population who still hold fast to tradition and culture, so it is with nature and the environment is still awake preserved. In addition to the uniqueness and distinctiveness that is owned, the tourist village should have a wide range of supporting facilities to support the activities of tourism which takes place in it so it will make it easier for the visitors in the tourist activity. These criteria include:

\subsubsection{A typical ghetto Environment along with its customs and traditions.}

To become a township or village has its own characteristics, Sade Village must have its own potentialities as well. These potentialities contains 2 things:

a. Physical Potential, namely the community still maintains village environment of Sade and a traditional Sasak original architecture of the building.

b. The Non physical Potential in the form of sociocultural life of the community is still holding fast to Sade customs and cultural traditions of indigenous Sasak.

According to Hadinoto (1996), in the planning of tourism development, local characteristics should be studied seriously because it can be an interesting tourist attraction. The physical environment is a reflection of life of local communities is the image of the views of the community environment gives a big advantage to the development of tourism.

\subsubsection{Power support land (Carrying Capacity)}

Power support or capacity of the land to be considered include power support the physical, natural, social and cultural. The scale and type of tourist village facilities must reflect the limits of use that can be tolerated. Development of the hamlet of Sade as a tourist village should pay attention to the power support land and its continuity. Given the existence of the customs limit the number of custom homes by as much as 150 with 3 acres of village land. The construction and its development must be appropriate and in accord with the limits of the environment.

In addition, pay attention to the capacity and resource support of land is very important as a preservation quality and tourism facilities and primarily for the conservation of natural resources.

4.3.3. The fulfillment or the availability of the infrastructure with infrastructure

Infrastructure is what determines the smoothness and accelerated development. Infrastructure according to Basri, et al (2009) can be divided as follows:

1. physical hardware Infrastructure (physical hard infrastructure) which include highways, railways, airports, harbours and ports, dams and irrigation channels etc

2. hardware Infrastructure nonphysical (nonphysical hard infrastucture) relating to public utility functions such as availability of clean water following the installation of water treatment and distribution pipelines; electricity supply; telecommunication networks (telephone, internet); and the supply of energy ranging from biodiesel, petroleum, and natural gas distribution pipeline network here.

3. software Infrastructure or commonly referred to as the institutional framework which includes a range 
of values (including work ethic), norm (especially one that has been developed and codified into legal regulations and legislation) as well as the quality of service the public is provided by various relevant parties especially Government.

The third type of infrastructure the vital role because ketiga-tiganya is an instrument to drive the national economy. The availability of infrastructure facilities will stimulate the development of a region or country. The sooner and the great economic development that would digerakan, more and more facilities.

Infrastruktur required. Without adequate infrastructure, availability can be ensured an economic activity or development in General will walk a trembling voice. Tourist village should have a wide range of facilities available as a tourist destination, to make it easier for visitors to conduct tourism activities. The facilities provided are transportation, telecommunications, health and also accommodation. For special means of accommodation, tourist villages provide lodging in the form of tourist lodges (home stay) so the feel of the plundering of the countryside is still original.

4. the management and human resources Management

As delivered by the Directorate of community empowerment Ministry of tourism and the Creative Economy (2016) that form the management of village tourism is essentially a community-owned privately either, considering some aspects of It is important in the management of such; (1) aspects of human resources, (2) the financial aspects, (3) material aspects, (4) aspects of management and (4) aspects of the market. In one container of community organizations in the form of partnerships, the management of the Corporation, Foundation or property management village items $\neg$ elements management recruited from the local community and more capabilities give precedence to the role of the youth have the educational background or skills required.

Management the management of a tourist village should be done by the local community. The Community institution or organization of the village acts as a facilitator with the stakeholders as well as the Government and implementing technical or program manager tourism village. The
Community institutions will never be separated from the utilization of human resources in the local village community. With the pioneering local institutional development such as maximizing the role of Conscious Group tours (Pokdarwis) for the management of the tourist village. Human resources readiness in tourist villages will maximize the role of these institutions in managing tourism so that at the level of the already advanced this institution will be able to develop a network of village cooperation at the regional level as well as nationally. Institutional strengthening is required (local institutional strengthening) and local leadership (local leadership) in order to support the success of the management of the tourist village.

Next in greater coverage is extensive, as it poured in RIPPARDA (Regional Tourism Development master plan) in 2013-2028 province of Nusa Tenggara Barat that developing institutional and governance of Tourism tourism able to synergize the development of tourism destinations, tourism marketing, and tourism industry professionally, effectively and efficiently is the purpose of the construction of the tourism area.

Economic growth thus represents the primary means for human resource development especially in equitable economic growth and sectoral conducive towards job creation. This automatic relationship indeed merupakakn the challenge for implementing government policy for the steady, so the two are mutually reinforcing. Implementation of the development of human resources (HR), can be done through education, training and participation in seminars, discussions, etc, as well as in the fields of tourism. The education needed to staffs that will be employed in managerial activities. To that end, we recommend that you assigned to the younger generation of the village in question to be educated in the schools of tourism, while the training given to those who will be given the task of accepting and serving tourists. Participation in seminars, discussions, and others given to the officers of tourism in village, district, and County, because the villagers generally only have the skills of farming.

5. The role of Government

The role of Government is crucial in the development of the tourist village. The usual Government role more emphasized, namely in 
terms of aid funds. Government's role in funding the very need for, because the village may not be able to innovate and tourists visit for the purposes of adaptation. Then gradually to consider subsidies towards the village or held a special project within the framework of the construction of a tourist village.

Prof. Ir. Kusdianto Hadinoto in planning the development of a Tourism Destination, the province of West Nusa Tenggara is one of the leading Tourism Destinations nationwide are currently being developed and developed well done by the Central Government, local governments as well as the public widely. The Central Government through the Ministry of culture and tourism together with Department of culture and tourism of the province and Kabupaten/Kota have been carrying out programs involving the community in the village and surrounding Villages namely or Program National community empowerment (PNPM) Independent tourism in the province of West Nusa Tenggara. Help the simultaneous nature of the tourist village and is designed to provide an opportunity to the public in developing the capacity of communities and expand the opportunity of trying activities in tourism. The use of the grant village prioritized on the collective activity and directly touch the poor. Therefore, poverty reduction through tourism requires a strategy and guidelines for the preparation of programmes of action is the right fit characteristics associated with tours and permasasalahan or around the village.

The role of Government in tourism policy determine the strategic and responsible for some of the following:

1. build framework (framework) operations in which the public and private sectors involved in moving the pulse of tourism;

2. Providing and facilitating the needs of legislation, regulation and control are applied in tourism, environmental protection, and preservation of culture and cultural heritage;

3. Provide and build transportation infrastructure of air, land, sea communication infrastructures with completeness;

4. Establish and facilitate an increase in the quality of human resources with the guarantee of professional education and training to supply the need of manpower in the tourism sector;

5. Translating tourism policy arranged in concrete plans that may be entered therein and are aligned with the condition of the local community.

Level 4 is an alternative strategy will be undertaken as an effort towards the development of the region's tourist Villages. Sade Development of the region of the village of Sade in fact is the increase in the value of the benefit for the community and the region became the driving force of economic growth for the community surrounding the village come with commonality of customs and culture. One of the efforts to improve conditions of kampung Sade from both the social aspects, culture and environment is to conduct ongoing Setup and maintain its existence and its identity as one of the Lombok Sasak community the traditional culture is still maintained and made as sustainable tourism village. In order for the cultural meanings contained in the hamlet of Sade can remain well maintained and still can bring economic benefits for the community of Sade and surrounding areas, then there are 3 (three) offered a strategy in an effort to development of the region in the form of Setup for further utilization of:

1. The replication of the hamlet of Sade

As stated in the Charter of the Burra (1981) PP $36 / 2005$, /UNESCO definition of replication is the attempt to rebuild a new reconstruction by mimicking certain forms that ever existed in the past, this aims to symbols that are economic/commercial than cultural-aesthetic. Replication is one of the region's conservation activities undertaken not only by retaining the authenticity of its physical but also bring economic value or other benefits for society at large.

As an effort in doing the development area of the hamlet of Sade tour village, attempt replication offered is Sade the original left with architecture and its authenticity while maintaining their local wisdom. Not far from the small scale settlements established Sade resembles the model building and environment Sade original. The allocation is as a homestay, display art attractions and other economic activities in order to meet the needs of tourists. This tourist facilities managed by local people.

\section{Relocation of the village of Sade}

This preservation effort is executed on the basis of due to the characteristics of the surrounding environment as well as its value is considered less suitable again for the physical structure that would like to keep. Then transfer to the new 
location shall be deemed to be able to further guarantee the value and physical form that wants to keep.

This approach is also presented by Soemarno (2010) as one of the efforts is a tourist village development approach with mengonservasi the whole village and provide new land to accommodate the development of the villagers and simultaneously developing the land as a tourism area with tourist facilities.

The concept of development of the region with a relocation strategy offered to the respondents was the relocation of the village Sade do conserve the overall Sade and provide new land to accommodate the development of the population and at the same time developing the the land as a tourism area (economic activity), agricultural areas and villages connected with the customs of the area of the village-the village around (as Sade 2) relative have in common customs and potentially as an object of tourism. So by doing relocation, presence of Sade can as the catalyst for the growth of the surrounding area. Ketelibatan private parties as well as an investor by involving the community as the Manager.

\section{Revitalization of the village of Sade}

Revitalization is a preservation efforts in reviving something (building, environment or area of a city) that have become extinct, where in the past such things never succeed and that then has lost the (extinct) It aims to draw public activities within the framework of the economic and cultural (Unesco. PP. 36/2005)

Revitalizing activities aiming to obtain optimal added value in economic, social and cultural in the utilization of buildings and the environment to prevent the loss of assetaset in an area of historical value due the onset of decline, degradation or a decrease in productivity in the area.

Referring to the above definition, the concept of revitalization can be done is Sade still left as the original to do a treatment against defective parts as well as conserve a number of houses that have cultural value and architecture the height by changing the function of the home into a museum village. Maximize utilization of houses as a home stay and providing means of support.

\section{CONCLUSION AND SUGGESTION}

\subsection{Conclusion}

Setup format Model of traditional Tourism tourism in the hamlet of Sade and hamlet of Lombok's tourism Segenter with the aim to be achieved, namely Enhancing public participation, increase the length of stay of tourists, Cultural Preservation criteria must-have a typical Ghetto
Environment and customs, power Support Infrastructure, the availability of Land and Infrastructure, as well as the management and human resources and the critical role of Government

Village of Replication strategies used Sade, Sade Village Relocation Village Revitalization Sade The priority of the right strategy to be used in an effort to develop the village

Sade as a tourist village that is -at level 4, that is territory development strategy Hillbilly Sade tour, selected as the village Revitalization -at level 3, i.e. the criteria used for support purposes in order for the achievement of business goals in the development area of the hamlet of Sade as a tourist village is to maintain the environment of a typical village with their customs and traditions became a priority Next, followed by support from the role of Government, management and human resources management, the availability of infrastructure, including facilities and infrastructure, and the availability of resources support farm hamlet of Sade.

-at level 2, that is a goal that will get after doing strategy and criteria, then a goal so priority i.e. preservation of culture, and then increase the length of stay of tourists and increase public participation.

\subsection{Suggestions}

As for suggestions that can be delivered from the results of this research are:

The role of the Government in the planning and execution of development the village revitalization efforts in doing Sade hamlet of Sade, should give priority to its continuity and support resources so that any form of arrangement that is done can be enabled with as well as not damaging the originality and the Sade environment;

Private parties in this case the perpetrators should increase tourism of creativity in the provision of tourist packages that are competitive with the local wisdom repackaged Sade as a decent sale event agenda;

For local people, should be aware of the importance of environmental hygiene around especially in improving the comfort of travelers in the hamlet of Sade. Showing the authenticity that the hamlet of Sade are identical to the traditional does not mean things cinematic hamlet of Sade.

\section{REFERENCES}

[1] Antariksa, Basuki, (2016), The development policy of tourism, Malang, Intrans Publishing,

[2] Winarny susyanti, (2013), The potential of the village through rural tourism, Economic and Business Journal, Vol 12, no. 1, June 2013 
[3] Irfan, Mohammad, (2012), Management of Coastal and Marine Resources through empowerment of local wisdom In north Lombok Regency, FH Legal Laboratory University of Mataram, not published.

[4] Atmosudiro, Sumijati, D.S. Nugrahani, Chr. Pensions Nugraha Rich., Sektiadi, (2003). The potential and opportunities of developing Traditional Lombok Weaving, Research Grant Competitive higher education Department.

[5] Ismellina Mella, FR, (2015), Management of Coastal and Marine Resources Towards Suistainable Development, Journal of rituals of Madani, FH Unisba Volume VII No. 3 November 2005

[6] Janianton damanik dkk, (2014), Building Tourism from below, Gadjah Mada University Press, Yogyakarta.

[7] Maksimilianus Maris Jupir, (2013), Tourism Policybased Implementation of local wisdom (West Manggarai Regency in the Study), the Journal of Indonesian Tourism and Development Studies, vol. 1, no. 1, January, 2013.

[8] Mulyadi A.J., Warman Andri, (2014), Tourism and travel, King Grafindo Persada, Jakarta

[9] Nanik L Gale, (2012), Sade Bungin Sambori, and other unique places in Lombok, Sumbawa, Bima Samparaja Culture Museum of West Nusa Tenggara

[10] The main Rai I Gusti Bagus, (2015), Development of the city as a future Tourism Indonesia, Researc Gate.

[11] Sumijati Atmosudiro DKK, (2007), Cultural tourism Model Based Weaving on Lombok, Competitive higher education Grants Research report Mone

[12] Soekadijo, (2000). Tourism: understanding the anatomy of tourism as "a Systemic Linkage". Jakarta: PT Gramedia Pustaka Utama.

[13] Susilowati, Diana, (2013), the Betawi Cultural Village Preservation Effort in Setu Babakan As Cultural tourism area, Journal of Engineering Volume 2 number PWK, 2013

[14] Sulaiman, (2012), traditional wisdom in the management of Fishery Resources in Aceh special autonomy in the Era, in the journal of laws of dynamics, vol. 11, may 2012

[15] Steadfast, Frans, (2015), governance, building a Destination Tourism Ecosystem, Gadjah Mada University Press, Yogyakarta Wardiyanta, 2010, research methods of tourism, Andi Publisher, Yogyakarta. 